这

||

\title{
KOMUNIKACJA MATKI Z DZIECKIEM W OKRESIE PRENATALNYM
}

ABSTRACT. Joanna Matuszczak-Świgoń, Anna Kowalska-Żelewska, Komunikacja matki z dzieckiem w okresie prenatalnym [Mother's communication with her child in a prenatal period] edited by M. Obrębska, L. Bakiera, „Człowiek i Społeczeństwo” vol. L: Psychologiczne konteksty komunikacji interpersonalnej [Psychological contexts of interpersonal communication], Poznań 2020, pp. 85-99, Adam Mickiewicz University. ISSN 0239-3271, https://doi.org/10.14746/cis.2020.50.6.

The aim of this paper is to present theories, current research on the forms and importance of a mother's communication with her child in a prenatal period, and discuss the results of own research in this area. In the research, the Communication with a Prenatal Child Questionnaire was used which measures six forms of prenatal communication. Prenatal communication is significant for both a mother and a child in her womb. Thanks to prenatal communication the mother can explore more consciously the challenges of pregnancy which are preparatory tasks for the role of a parent and the child develops better. The mother learns how to express her feelings non-verbally through empathy, facial expressions, touch, synchrony, and intuition. After childbirth, she can use the forms of communication from the prenatal period.

Keywords: prenatal communication, pregnancy

Joanna Matuszczak-Świgoń, Uniwersytet im. Adama Mickiewicza w Poznaniu, Wydział Psychologii i Kognitywistyki, ul. A. Szamarzewskiego 89/AB, 60-568 Poznań, jm4611@amu.edu.pl, ORCID: https:// orcid.org/0000-0001-5188-3040.

Anna Kowalska-Żelewska, Laboratorium Psychoedukacji, ak.annakowalska@gmail.com. 


\section{Wprowadzenie}

Celem artykułu jest przedstawienie wyników badań własnych na temat komunikacji matki z dzieckiem w okresie prenatalnym. Problematyka ta jest podejmowana w badaniach naukowych (Bielawska-Batorowicz, 1995; Brazelton i Cramer, 1990; Zeanah, Keener, Stewart i Anders, 1985), ale brakuje metod do badania komunikacji z dzieckiem w okresie prenatalnym. Próbę operacjonalizacji więzi emocjonalnej z dzieckiem, w skład której wchodzi komunikacja z nim, podjęła Mecca Cranley w 1981 r. (polska adaptacja Eleonory Bielawskiej-Batorowicz, 1995). W zaproponowanym przez autorkę ujęciu interakcja z dzieckiem jest jednym z sześciu aspektów przywiązania między matką a nienarodzonym dzieckiem.

Między 16. a 20. tygodniem ciąży matka po raz pierwszy zauważa ruchy dziecka. Z każdym miesiącem ciąży przybywa tych ruchów: średnia ich liczba w ciągu dnia wzrasta z ok. 200 w 20. tygodniu ciąży do maksimum 575 w 32. (w trakcie porodu średnio 282), a liczba ruchów indywidualnego dziecka może się wahać od 50 do 956 (Brazelton i Cramer, 1990). W tym czasie matka próbuje nadawać znaczenie tym ruchom, rozumieć zachowanie dziecka, stara się określić jego osobowość, temperament, nadaje mu pewne cechy, nazywając je „spokojnym”, „cichym”, „,̇ywym”, „nerwowym”. Matka spostrzega ruchy dziecka, jakby były one intencjonalną komunikacją i odpowiada na nie zgodnie z nadanym przez siebie sensem. Ponadto, matka przypisuje dziecku w swym łonie stany emocjonalne. Zdaniem Thomasa Brazeltona i Bertranda Cramera (1990) jest to wyraz powszechnej potrzeby poznania swojego dziecka.

Ruchy dziecka prenatalnego służą wielu celom: eksploracji, ochronie, wyrażaniu swojej indywidualności oraz komunikacji. Jeśli środowisko jest wystarczająco stymulujące, to dzieci już w łonie matki są gotowe do wysyłania i odbierania wiadomości bez użycia słów, które pojawiają się rok lub dwa po urodzeniu. Ta forma komunikacji występuje nie tylko w okresie prenatalnym, ale również po narodzinach i trwa przez całe życie, stanowiąc uniwersalny język (Chamberlain, 1999b; Kornas-Biela, 2004; Marx i Nagy, 2015; Vasta, Haith i Miller, 2004). 


\section{Formy komunikacji z dzieckiem w okresie prenatalnym}

Komunikacja z dzieckiem prenatalnym obejmuje te aktywności matki, które są przejawem uznania odrębności i obecności dziecka oraz pomagają w procesie nawiązywania z nim więzi. W literaturze wyróżnia się sześć form komunikacji z dzieckiem w okresie prenatalnym, które omówiono poniżej (Bielawska-Batorowicz, 1995; Kornas-Biela, 2004).

\section{Wyobrażeniowe myślenie o dziecku}

Matki często wyobrażają sobie, jak dziecko się zachowuje, jak wygląda, zastanawiają się, co robi w danym momencie, jaki ma nastrój. Tworzy się wówczas obraz „dziecka wyobrażonego”. Ulega on modyfikacji, gdy dziecko pojawia się na świecie (Raphael-Leff, 1993). Matka nadaje dziecku prenatalnemu tożsamość, przypisując mu całą gamę cech, które są zawsze powiązane z jej linią pochodzenia. W ten sposób nadaje nieznanemu znamiona swojskości, co redukuje jej lęk (Cramer, 2003).

Kobieca wyobraźnia intensywnie pracuje, próbując nadać kształt życiu, które ją czeka po narodzinach dziecka. Umysł w czasie ciąży przypomina przestrzeń, w której przyszłość cały czas jest budowana i na nowo konstruowana. Kobieta odgrywa wyobrażone scenariusze z udziałem wyobrażonych postaci: z dzieckiem, sobą jako matką, przyszłym ojcem, dziadkami. Próbuje odgadnąć, jakie jest jej dziecko. Te wyobrażenia wiele mówią o wartościach i priorytetach kobiety. Każda matka mentalnie konstruuje swoje dziecko z własnych nadziei, marzeń i lęków. Rozszerza też swoje wyobrażenia i zastanawia się, jak jej dziecko będzie wyglądało, gdy skończy roczek, pójdzie do szkoły i będzie osobą dorosłą. Jest to sposób na oswojenie się z nową sytuacją. Taki wyimaginowany świat jest mentalnym etapem, w którym można wymyślić i przećwiczyć różne możliwe rozwiązania (Stern, 1998).

Badania przeprowadzone przez Charlesa H. Zeanaha, Marcię A. Keener, Lindę Stewart i Thomasa F. Andersa (1985) udowadniają, że umysłowe reprezentacje niemowlaków powstają w umyśle matki już w czasie ciąży i pozostają dość stabilne we wczesnym niemowlęctwie. Trwałość przypisywanych cech dziecku w okresie ciąży i po porodzie dotyczy takich aspektów jak: temperament, poziom aktywności, regularność zachowań, nastrój. Udowodniono stałość tych właściwości od trzeciego trymestru ciąży do szóstego miesiąca życia. 


\section{Rozmowy z dzieckiem}

Kontakt konwersacjopodobny realizowany za pomocą środków niewerbalnych i werbalnych (ze strony matki) może się odbywać w formie monologu lub wyimaginowanego dialogu. Monologiem będzie czytanie bajek, wierszy, opowiadanie historii. Rozmowę (w formie wyimaginowanego dialogu) można prowadzić głośno lub w ciszy, w myślach. Choć dziecko nie odpowiada słowami, czasem reaguje ruchowo, a matka zachowuje się, jakby słyszała odpowiedź, która ma wpływ na jej dalszą interakcję (Kornas-Biela, 2004).

Pokazano, że dziecko w łonie reaguje na głos matki między 32. a 34. tygodniem ciąży (Kisilevsky i Hains, 2011), a przed porodem potrafi go rozpoznać (Voegtline, Costigan, Pater i DiPietro, 2013). Ponadto, dziecko prenatalne potrafi odróżnić głos matki od obcego żeńskiego głosu (Kisilevsky, Hains i Lee, 2003), co świadczy o tym, że już w okresie prenatalnym uczy się, zapamiętuje i rozpoznaje pewne właściwości głosu matki. Ta nauka jest najprawdopodobniej oparta na prozodycznych cechach języka, przyswajanych w łonie matki. Badania pokazują również, że pod koniec ciąży dzieci potrafią odróżnić rymowankę, którą matka głośno recytowała podczas ostatnich czterech tygodni ciąży (tętno dziecka spada), od nowego wierszyka, którego wcześniej nie słyszały (brak zmian w tętnie) (DeCasper, Lecanuet, Busnel, Granier-Deferre i Maugeais, 1994), co świadczy o wcześnie rozwiniętej percepcji języka i umiejętności uczenia się. Ponadto, po narodzinach, noworodki nie tylko potrafią odróżnić język ojczysty od obcego (Chamberlain, 1999b; Mehler, Jusczyk i Lambertz, 1988; Moon, Cooper i Fifer, 1993), ale również rozróżniać dwa obce języki na podstawie ich prozodii (Nazzi, Bertoncini i Mehler, 1998). Udowodniono też, że noworodki rozpoznają i preferują znane sekwencje mowy, które matka głośno wypowiadała w ostatnich tygodniach ciąży, w porównaniu z nowymi wypowiedziami, nawet jeśli znajome fragmenty są wypowiadane przez nieznany głos (Spence i DeCasper, 1987).

Chociaż mowa matki jest znacząco wyciszona w łonie, brzmieniowe właściwości mowy zostają zachowane (Spence i DeCasper, 1987). Niewerbalne aspekty mowy informują o emocjach, postawach, cechach osobowości oraz wpływają na wywierane wrażenie (Cheng, Lee, Chen, Wang i Decety, 2012). Niewerbalne komunikaty obejmują: intonację, natężenie głosu i akcent, tempo i rytm mówienia oraz pauzy. 


\section{Śpiewanie dziecku}

Śpiew ma dobroczynny wpływ na układ nerwowy i rozluźniająco wpływa na dziecko w łonie, dlatego obecny jest w wielu kulturach. Śpiew może usypiać, ożywiać, rozbawiać, a także pobudzać rozwój komórek nerwowych (Kornas-Biela, 2004). Udowodniono, że noworodki rozpoznają i preferują melodie, które matki wielokrotnie śpiewały w ostatnich tygodniach ciąży (Cooper i Aslin, 1989).

Rosario Montemurro (1996) wraz ze współpracownikami przeprowadziła eksperyment w Walencji, który polegał na tym, że kobiety w ciąży śpiewały kołysanki swoim nienarodzonym dzieciom. Okazało się, że śpiew jest dobrym sposobem wyrażania intymnych, głębokich uczuć. W trakcie śpiewu kobiety czują, że dzieci przyłączają się do nich poprzez harmonijne i spontaniczne ruchy w łonie. W rezultacie poprzez śpiew zacieśnia się więź między matką a dzieckiem.

Śpiewanie może też przygotować kobietę do akcji skurczowej w trakcie porodu. Śpiewając, uczy się ona oddychać rytmicznie, używać mięśni brzucha, rozluźniać klatkę piersiową oraz zwiększać pojemność płuc (Montemurro, 1996).

\section{Słuchanie muzyki}

Muzyka ma inną jakość niż mowa, a śpiew dorosłej osoby różni się rozkładem fal akustycznych, dlatego jest odmiennie odbierana, pobudzając inne ośrodki nerwowe w mózgu dziecka. Dziecko w łonie reaguje na muzykę poprzez ruch oraz zmianę rytmu serca (Parncutt, 2016).

Dziecko inaczej reaguje na muzykę uspokajającą, o tempie odpowiadającym częstotliwości uderzeń serca dorosłego w stanie spoczynku. Na przykład koncerty Bacha, Mozarta, Schumanna, Debussy'ego, Czajkowskiego czy Vivaldiego wywołują delikatne, rytmiczne kopnięcia dziecka. Taka muzyka bowiem normalizuje pracę serca i fal mózgowych. Inne skutki wywołuje natomiast słuchanie muzyki rockowej, która powoduje gwałtowne, nierówne ruchy dziecka (Kornas-Biela, 2004).

\section{Dotyk}

Dotyk jest pierwszym zmysłem, za pomocą którego doświadcza się świata zewnętrznego. W okresie prenatalnym dziecko poznaje otaczające je 
środowisko, dotykając pępowiny, ścian worka płodowego i samego siebie. Ponadto reaguje na rytm serca matki, który odbiera całym ciałem.

Dotyk stanowi najbardziej podstawową i naturalną formę komunikacji, zachęca do wysiłku, służy okazywaniu czułości i wsparcia emocjonalnego (Knapp i Hall, 1997). Komunikatem w kanale dotykowym jest zmiana, która może dotyczyć siły nacisku, miejsca dotykania lub obu tych aspektów równocześnie (Domachowski, 1993).

Pocierając lub stukając w powłoki brzuszne, matka może zachęcić dziecko do aktywności i rozpocząć swoisty dialog: dziecko zaczyna kopać, budzi się, przesuwa rączkami, nóżkami po ściankach brzucha. Poprzez głaskanie, klepanie matka może mu przekazywać szereg uczuć (Marx i Nagy, 2015). Rene Van de Carr (1998) nazwał taki sposób komunikacji prenatalnym uniwersytetem. Udowodnił, że dzieci masowane i dotykane z troską zarówno przed, jak i po urodzeniu rozwijają się lepiej fizycznie i psychicznie, dotyk stymuluje ich mózg.

\section{Mechanizm synchronizowania matki i dziecka prenatalnego}

W codziennym życiu ludzie zanurzeni są w „oceanie” rytmu, który jest wszechobecny w komunikacji. Dziecko w łonie potrafi tworzyć różne wzorce rytmiczne, które obejmują: tętno, ruchy oddechowe, czkanie, ssanie, poruszanie rękoma i nogami, wąchanie oraz połykanie. Większość tych czynności generowana jest automatycznie na poziomie podkorowym, ale podlega modyfikacji pod wpływem wewnętrznych i zewnętrznych bodźców, zwłaszcza zachowań matki. Tętno płodu stanowi jeden z najczęstszych wskaźników stosowanych do badania reakcji dziecka płodowego na zewnętrzną stymulację (Provasi, Anderson i Barbu-Roth, 2014). Sensoryczno-motoryczna synchronizacja oznacza umiejętność koordynacji rytmicznych ruchów z zewnętrznym rytmem i występuje tylko u gatunków zdolnych do uczenia się wokalizacji. Zsynchronizowane zachowania można postrzegać jako podstawy dla tworzenia się więzi społecznych (Provasi i in., 2014). Mechanizm synchronizowania polega na tym, że osoby wzajemnie dopasowują do siebie swoje zachowania motoryczne i rytmiczne sygnały słuchowe. Synchronizacja odgrywa kluczową rolę w interakcjach społecznych, ponieważ jest skutecznym sposobem komunikowania, że sygnały pochodzące z zachowania innej osoby zostały odebrane. Wzór takiej synchronizacji stanowi interakcja między matką a dzieckiem w jej łonie: matka dostarcza dziecku stymulacji składającej się z rytmicznych schematów podczas oddychania, aktywności serca, spacerowania, mówienia, śpiewania, a ono odpowiada na jej oddziaływania poprzez wzorce rytmicznej aktywności. Ponadto, dziecko wewnątrz 
łona, zwłaszcza od trzeciego trymestru, dopasowuje się do rytmu matki: gdy ona aktywizuje swoje działania - jest spokojne, natomiast gdy ona odpoczywa - zaczyna się ruszać (rytm naprzemiennej aktywności). W okresie ciąży matka i dziecko stanowią zgrany duet: połączeni są zmysłami, emocjami oraz postrzeganiem zewnętrznych wydarzeń (Chamberlain, 1999a).

\section{Funkcje komunikacji prenatalnej}

Stymulacja prenatalna ma szereg zalet. Poprzez komunikację prenatalną matka pokazuje swoje przywiązanie do dziecka (Bielawska-Batorowicz, 1995). Ponadto, komunikacja ta ma wpływ na rozwój uczuć rodzicielskich. Próbując interpretować potrzeby dziecka, matka uczy się ich zaspokajania (Kornas-Biela, 2004).

Śpiew, głos, dotyk, muzykę dziecko odbiera jako odrębne bodźce, analizuje je, zapamiętuje, w oparciu o nie buduje swoje nawyki, upodobania oraz umiejętności. Komunikacja prenatalna wprowadza asocjacyjny proces uczenia, który wpływa na dziecko poprzez jego zmysły. W rezultacie mózg dziecka trenuje swoje funkcje, powstają nowe połączenia między synapsami, z których rozwijają się zalążki inteligencji zmysłowo-ruchowej (Van de Carr, 1998).

Już w okresie prenatalnym dziecko demonstruje swoje interakcje społeczne w uczeniu się fragmentów muzyki, opowiadań, głosu rodziców oraz dźwięku ich ojczystego języka. Badania spektrografem wykazały, że pierwszy krzyk 900-gramowego dziecka zawiera już takie elementy jak: intonacja, rytm i inne cechy mowy dopasowane do głosu matki. W ten sposób udowodniono, że już w 26. tygodniu ciąży dziecko przyswaja sobie pewne prozodyczne cechy języka matki (Chamberlain, 1999b).

Stymulacja prenatalna ma też dobroczynny wpływ na rozwój dziecka: genetycznie zaprogramowane zdolności występują wcześniej i w pełniejszy sposób wykorzystują potencjał (Kornas-Biela, 2004).

\section{Badania własne}

\section{Cel, problemy i hipotezy badawcze}

Celem badania było sprawdzenie, jakie formy komunikacji z dzieckiem prenatalnym są podejmowane najczęściej oraz które z wybranych zmiennych mają związek z podejmowaniem zróżnicowanych form komunikacji 
prenatalnej. Badanie było częścią projektu, w którym łączono analizę jakościową (narracje matki o dziecku w okresie prenatalnym) i ilościową (Matuszczak-Świgoń, 2014). W wyniku poczynionych teoretycznych ustaleń sformułowano następujące pytania badawcze:

1. Czy istnieje związek pomiędzy zaawansowaniem ciąży a różnorodnością form komunikacji z dzieckiem prenatalnym?

2. Czy istnieje różnica w podejmowaniu różnorodnych form komunikacji z dzieckiem prenatalnym ze względu na płeć dziecka?

3. Czy istnieje różnica w podejmowaniu różnorodnych form komunikacji z dzieckiem prenatalnym u kobiet spodziewających się pierwszego dziecka i kobiet oczekujących narodzin kolejnego dziecka?

4. Jak często matki podejmują poszczególne formy komunikacji z dzieckiem prenatalnym?

Sformułowano następujące hipotezy:

1. Im bardziej zaawansowana ciąża, tym bardziej zróżnicowane formy komunikacji z dzieckiem w okresie prenatalnym.

2. Występuje różnica w podejmowaniu zróżnicowanych form komunikacji w okresie prenatalnym ze względu na płeć mającego się narodzić dziecka. Matki dziewczynek w bardziej zróżnicowany sposób komunikują się z nimi w okresie prenatalnym niż matki chłopców.

3. Kobiety spodziewające się pierwszego dziecka podejmują bardziej zróżnicowane formy komunikowania się z nim niż kobiety oczekujące narodzin kolejnego dziecka.

\section{Osoby badane}

Dobór osób do badań był celowy. Badaniami zostały objęte kobiety powyżej 16. tygodnia ciąży, ponieważ wówczas matka zaczyna odczuwać ruchy dziecka, co jest kluczowe dla komunikacji z nim. Za pomocą kwestionariusza przebadano 71 kobiet. W pozyskaniu osób do badań korzystano z pomocy profesjonalistów z gabinetów ginekologicznych, szkół rodzenia i internetowych forów dla kobiet w ciąży.

Spośród 71 kobiet, z którymi rozpoczęto badania, do ostatecznej analizy zakwalifikowano materiały badawcze uzyskane od 67 kobiet, ponieważ 4 osoby były dopiero w pierwszych tygodniach ciąży (w 6., 13. i 10. tygodniu ciąży). Charakterystykę matek zawarto w tabeli 1. 
Tabela 1. Charakterystyka badanych kobiet $(N=67)$

\begin{tabular}{|l|l|}
\hline Elementy charakterystyki & Osoby badane \\
\hline Wiek & $19-37, M=28, S D=12,7$ \\
\hline Wykształcenie: & $49(73 \%)$ \\
wyższe & $13(19 \%)$ \\
średnie & $5(8 \%)$ \\
zawodowe & $1-14, M=7,5, S D=9,2$ \\
\hline Czas trwania związku intymnego & $16-39, M=27,5, S D=16,3$ \\
\hline Tydzień ciąży & \\
\hline Płeć dziecka: & $30(45 \%)$ \\
chłopiec & $23(34 \%)$ \\
dziewczynka & $14(21 \%)$ \\
nieznana & \\
\hline Szkoła rodzenia: & $17(25 \%)$ \\
tak & $42(63 \%)$ \\
nie & $8(12 \%)$ \\
zamierzam &
\end{tabular}

Źródło: opracowanie własne.

\section{Narzędzia}

Podczas badania posłużono się Kwestionariuszem Komunikacji z Dzieckiem Prenatalnym (KKzDzP) wraz z metryczką (narzędzie własne). Składał się on z 29 pozycji dotyczących różnych form komunikacji z dzieckiem mającym się narodzić, takich jak: wyobrażeniowe myślenie o dziecku, rozmowy z dzieckiem, śpiewanie dziecku, słuchanie muzyki, dotyk, mechanizm synchronizowania. Ustosunkowując się do twierdzeń, respondentki korzystały z 5-stopniowej skali (od nigdy do zawsze), określając w ten sposób częstotliwość podejmowania komunikacji z dzieckiem. Wynik ogólny tworzyła suma uzyskanych punktów - im wyższa, tym bardziej różnorodna komunikacji. Analiza psychometrycznych parametrów kwestionariusza wskazała, że jest to narzędzie rzetelne: współczynnik alfa Cronbacha wynosi 0,94.

Zróżnicowanie form komunikacji z dzieckiem w okresie prenatalnym zmierzono, obliczając średni wynik uzyskany przez osobę badaną w KKzDzP.

\section{Przebieg badań}

Badanie przeprowadzono drogą mailową. Wiadomość o badaniu umieszczana była na forach dla kobiet w ciąży, w poradniach ginekologicznych 
oraz szkołach rodzenia. W pierwszym mailu poproszono o wyrażenie zgody na udział w badaniu, zapewniono o pełnej anonimowości i dyskrecji oraz poinformowano o naukowym charakterze badań. Następnie, również drogą mailową, wysłano kwestionariusz i metryczkę.

\section{Wyniki}

Wszystkie analizy statystyczne wykonywano za pomocą pakietu statystycznego SPSS. Pierwsza hipoteza - zakładająca, że im wyższy jest stopień zaawansowania ciąży, wyrażony tygodniem ciąży, tym większa różnorodność komunikacji z dzieckiem w okresie prenatalnym - nie została potwierdzona $\left(r_{s}=0,60\right)$. Płeć prenatalnego dziecka także nie różnicowała badanych osób ze względu na zróżnicowanie komunikacji (jednoczynnikowa analiza wariancji 0,779). Nie można było zweryfikować hipotezy o różnicach w podejmowaniu zróżnicowanych form komunikacji między kobietami spodziewającymi się pierwszego dziecka a kobietami oczekującymi narodzin kolejnego dziecka, ponieważ w badaniu wzięły udział głównie kobiety będące po raz pierwszy w ciąży. Można jednak spodziewać się takich różnic, ponieważ kobiety oczekujące pierwszego dziecka budują całkowicie nową mentalność, zasadniczo inną od dotychczasowej, wkraczają w sferę doświadczeń dotąd nieznanych. Okres oczekiwania na urodzenie pierwszego dziecka to przygotowawczy etap kształtowania się tożsamości macierzyńskiej (Stern, 1998). Założenia te potwierdzają wyniki duńskiego badania przywiązania matki do dziecka w okresie prenatalnym (Ertmann i in., 2021). Autorzy badania zwracają także uwagę na to, że kobiety posiadające dzieci, kobiety lepiej wykształcone i kobiety starsze wykazują mniejsze zaabsorbowanie dzieckiem w łonie (uzyskały niższe wyniki w skali przywiązania matki do dziecka w okresie prenatalnym MAAS - Maternal Antenatal Attachment Scale), co tłumaczą przypisywaniem przez nie mniejszej wartości macierzyństwu w rozumieniu poczucia spełnienia w tejże roli, a także większemu realizmowi i zaniepokojeniu zmianami zachodzącymi w organizmie w czasie ciąży.

Dane zawarte w tabeli 2 przedstawiają, z jaką częstotliwością matki podejmują poszczególne formy komunikacji z dzieckiem w okresie prenatalnym. Uzyskane wyniki wskazują, że matki najczęściej komunikują się ze swoim dzieckiem poprzez dotyk, a najrzadziej przez śpiewanie mu. 
Tabela 2. Częstotliwość podejmowanych przez matki form komunikacji z dzieckiem w okresie prenatalnym

\begin{tabular}{|l|c|}
\hline \multicolumn{1}{|c|}{ Forma komunikacji } & Średnia \\
\hline Wyobrażeniowe myślenie o dziecku & 2,67 \\
\hline Rozmowy z dzieckiem & 2,47 \\
\hline Śpiewanie dziecku & 1,82 \\
\hline Słuchanie muzyki & 2,25 \\
\hline Dotyk & 3,71 \\
\hline Mechanizm synchronizowania & 3,11 \\
\hline
\end{tabular}

Źródło: opracowanie własne.

\section{Dyskusja wyników}

Nie potwierdzono hipotezy zakładającej, że wraz ze wzrostem tygodnia ciąży zwiększa się częstotliwość komunikacji z dzieckiem. Przyczyną może być struktura odpowiedzi zastosowanych w kwestionariuszu, ponieważ odpowiedzi często i regularnie nie różnicują odpowiednio częstotliwości podejmowanych form komunikacji. Brak potwierdzenia tej hipotezy może również wynikać z tego, że wraz ze wzrostem wagi dziecka w łonie jego ruchy mogą budzić w matce dyskomfort i przeszkadzać jej w codziennym funkcjonowaniu. Matki mogą być też bardziej zaabsorbowane zbliżającym się porodem. Ponadto jest możliwe, że w badaniu kwestionariuszowym ujawniają się społeczne poglądy dotyczące tego, jak należy komunikować się z dzieckiem w okresie prenatalnym, co może wpływać na ujednolicenie wyników.

Rezultat braku różnic w częstotliwości komunikacji ze względu na płeć dziecka jest zgodny z badaniami, które pokazują, że w przypadku matek płeć dziecka nie stanowi czynnika wpływającego na więź z nim (McGuire, 1991). Ponadto wynik ten może świadczyć o tym, że nie sama płeć dziecka modyfikuje proces nawiązywania więzi emocjonalnej, lecz to, czy informacja o płci dziecka spełnia oczekiwania matki (Walker i Conner, 1993).

Matki najczęściej komunikują się ze swoim dzieckiem poprzez dotyk, a najrzadziej poprzez śpiewanie, co można wytłumaczyć tym, że dotykanie jest formą komunikacji niewerbalnej, w której kobiety mogą najpełniej przekazać swoje emocje. Przytulanie jest silnie związane z emocjonalnym wymiarem komunikacji. Ponadto, dotyk stanowi również jedną z najważniejszych 
form komunikacji po narodzinach dziecka. Śpiewanie dziecku zawarte było w kwestionariuszu tylko w jednym twierdzeniu: „Śpiewam mojemu dziecku” i warto podkreślić, że jest to czynność związana ze specyficznymi umiejętnościami, które nie każda matka posiada. Wysoki wynik uzyskano również w formie komunikacji określonej jako mechanizm synchronizowania, co może być traktowane jako wskaźnik przygotowywania się do spotkania z dzieckiem po narodzinach. To synchronizacja między matką a dzieckiem odgrywa bowiem kluczową rolę w pierwszych miesiącach sprawowania opieki nad niemowlęciem (Provasi i in., 2014; Marx i Nagy, 2015).

\section{Podsumowanie i implikacje}

Dialog w okresie ciąży nie tylko jest możliwy, ale przede wszystkim - potrzebny rodzicom i dziecku. Dziecko w łonie matki potrafi reagować na docierające do niego bodźce zmysłowe i emocjonalne, jak i odpowiadać na nie w zrozumiały dla rodziców sposób. Dzieje się tak, ponieważ matka nieustannie przypisuje intencje jego zachowaniom. Każdemu najdrobniejszemu sygnałowi nadaje znaczenie i właśnie na to znaczenie reaguje. Wszystko, co dziecko robi, zostaje natychmiast zakorzenione w systemie znaczeń. W rezultacie fantazje, wyobrażenia, doświadczenia matki wpływają na interakcję z jej dzieckiem (Bielawska-Batorowicz, 1995; Brazelton i Cramer, 1990; Kornas-Biela, 2004). Ponadto, sposób przeżywania świata przez matkę stanowi matrycę odbierania i doświadczania świata przez dziecko (Cramer, 2003; Parncutt, 2016).

W badaniu narracji matek o dziecku w okresie prenatalnym, które również stanowią jedną z form komunikacji, wykazano, że matki opowiadają o swoim prenatalnym dziecku w podobny sposób jak o niemowlęciu (Matuszczak-Świgoń, 2014). Zatem jeśli przyjmiemy założenie, że czynniki modyfikujące postrzeganie dziecka mogą też modyfikować sposób podejmowania interakcji z nim w okresie ciąży oraz traktowanie go po porodzie, okazuje się, że przeprowadzone badanie może służyć szeroko pojmowanej promocji zdrowia, edukacji na temat istotności komunikacji prenatalnej, profilaktyki położniczej, interwencji kryzysowej oraz psychologicznego poradnictwa dla kobiet w ciąży, obejmującego psychologiczne przygotowanie na zmiany, jakie spowoduje pojawienie się dziecka.

Wiedza na temat mechanizmów i korzyści wynikających z komunikacji prenatalnej jest coraz częściej wykorzystywana w praktyce klinicznej. Znaczenie dotyku w zmniejszaniu reakcji stresowej, rozwoju dziecka oraz 
wspomaganiu więzi między rodzicami a dzieckiem zarówno w okresie prenatalnym, jak i postnatalnym znajduje swoje odzwierciedlenie w kangurowaniu wcześniaków (Chrzan-Dętkoś, 2012) (co jest utrudnione lub uniemożliwione na oddziałach intensywnej opieki neonatologicznej oraz patologii noworodków w dobie pandemii COVID-19) (El-Farrash i in., 2020). Selena Williamson i Jacqueline M. McGrath (2020) zaproponowały wykorzystanie nagrań z głosem matki jako oddziaływań terapeutycznych wobec wcześniaków przebywających na oddziałach intensywnej terapii noworodków. Badacze z Indii natomiast wprowadzili trening wideo dla kobiet w ciąży, mający na celu zwiększenie świadomości roli komunikacji matki z dzieckiem w okresie prenatalnym, a także poprawę zdolności nawiązywania interakcji i wzmocnienia więzi między matką i dzieckiem (Monickaraj, Joseph i Kandasamy, 2020). W badaniu sugeruje się, że to kluczowy aspekt, który powinien być stałym elementem opieki okołoporodowej. Podobne badania (Neethu, Bhavya i Sheela, 2018) wskazują na znaczącą poprawę w relacji matki z dzieckiem w okresie prenatalnym dzięki koncentracji matki na ruchach dziecka.

Istnieje niewiele badań poruszających zagadnienie komunikacji ojca z dzieckiem w okresie prenatalnym. Badania nad wcześniakami (Saliba, Gratier, Filippa, Devouche i Esseily, 2020) wskazują, że dźwięk głosu ojca, podobnie jak matki, wpływa na zachowanie i pobudzenie noworodka, a zatem wydaje się ważne zbadanie tego zagadnienia w kontekście prenatalnym.

\section{Literatura}

Bielawska-Batorowicz, E. (1995). Determinanty spostrzegania dziecka przez rodziców w okresie poporodowym. Łódź: Wydawnictwo Uniwersytetu Łódzkiego.

Brazelton, T.B., Cramer, B. (1990). The Earliest Relationship: Parents, Infants, and the Drama of Early Attachment. Cambridge: Perseus Books.

Chamberlain, D.B. (1999a). Foundations of sex, love and relationships: From conception to birth. Journal of Prenatal and Perinatal Psychology and Health, 14(1), 45-64.

Chamberlain, D.B. (1999b). Prenatal body language: A new perspective on ourselves. Journal of Prenatal and Perinatal Psychology and Health, 14(1), 169-185.

Cheng, Y., Lee, S.Y., Chen, H.Y., Wang, P.Y., Decety, J. (2012). Voice and emotion processing in the human neonatal brain. Journal of Cognitive Neuroscience, 24, 1411-1419.

Chrzan-Dętkoś, M. (2012). Wcześniaki. Rozwój psychoruchowy w pierwszych latach życia. Gdańsk: Wydawnictwo Harmonia.

Cooper, R.P., Aslin, R.N. (1989). The language environment of the young infant: Implications for early perceptual development. Canadian Journal of Psychology, 43, 247-265. 
Cramer, B. (2003). Pierwsze dwa lata. Co się dzieje pomiędzy matkq, ojcem i dzieckiem. Gdańsk: Gdańskie Wydawnictwo Psychologiczne.

Cranley, M. (1981). Development of a tool for the measurment of maternal attachment during pregnancy. Nursing Research, 30, 281-284.

DeCasper, A., Lecanuet, J., Busnel, M., Granier-Deferre, C., Maugeais, R. (1994). Fetal reactions to recurrent maternal speech. Infant Behavior and Development, 17(2), 159-164.

Domachowski, W. (1993). Psychologia społeczna komunikacji niewerbalnej. Toruń: Wydawnictwo Edytor.

El-Farrash, R.A., Shinkar, D.M., Ragab, D.A., Salem, R.M., Saad, W.E., Farag, A.S., i in. (2020). Longer duration of kangaroo care improves neurobehavioral performance and feeding in preterm infants: A randomized controlled trial. Pediatric Research, 87(4), 683-688.

Ertmann, R.K., Bang, C.W., Kriegbaum, M., Væver, M.S., Kragstrup, J., Siersma, V., i in. (2021). What factors are most important for the development of the maternal-fetal relationship? A prospective study among pregnant women in Danish general practice. BMC Psychology, 9(2). DOI: https://doi.org/10.1186/s40359-020-00499-x.

Kisilevsky, B.S., Hains, S. (2011). Onset and maturation of fetal heart rate response to the mother's voice over late gestation. Developmental Science, 14, 214-223.

Kisilevsky, B.S., Hains, S., Lee, K. (2003). Effects of experience on fetal voice recognition. Psychological Science, 14, 220-224.

Knapp, M.L., Hall, J.A. (1997). Komunikacja niewerbalna w interakcjach międzyludzkich. Wrocław: Wydawnictwo Astrum.

Kornas-Biela, D. (2004). Wokół poczq̨tku życia ludzkiego. Warszawa: Instytut Wydawniczy Pax.

Marx, V., Nagy, E. (2015). Fetal behavioural responses to maternal voice and touch. PLoS ONE, 10(6): e0129118.

Matuszczak-Świgoń, J. (2014). Narracja matki o dziecku w okresie prenatalnym. Psychologia Rozwojowa, 19(1), 33-50.

McGuire, J. (1991). Sons and daughters. W: A. Phoenix, E. Woollett, E. Lloyd (red.), Motherhood. Meanings, practices and ideologies (s. 143-161). London: Sage.

Mehler, J., Jusczyk, P., Lambertz, G. (1988). A precursor of language acquisition in young infants. Cognition, 29, 143-178.

Monickaraj, J., Joseph, V., Kandasamy, V. (2020). Impact of video-assisted maternal training on focused concentration of fetal movements towards maternal fetal attachment/ bonding - A randomized controlled trial in a selected tertiary care hospital. Medicine and Public Health, 23(23), 1-17.

Montemurro, R. (1996). Singing lullabies to unborn children: Experiences in village Vilamarxant, Spain. Journal of Prenatal and Perinatal Psychology and Health, 11(1), 9-16.

Moon, C., Cooper, R., Fifer, W. (1993). Two-day-olds prefer their native language. Infant Behavior and Development, 16, 495-500.

Nazzi, T., Bertoncini, J., Mehler, J. (1998). Language discrimination by newborns: Toward an understanding of the role of rhythm. Journal of Experimental Psychology. Human Perception and Performance, 24, 756-766. 
Neethu, T., Bhavya, S.V, Sheela, W. (2018). Effect of fetal movement counting on prenatal attachment and maternal worries among primigravida mothers in selected Hospital, Mysuru. International Journal of Nursing Education and Research, 6(2), 200-204. DOI: 10.5958/2454-2660.2018.00045.5.

Parncutt, R. (2016). Prenatal development. W: G.E. McPherson (red.), The Child as Musician: A Handbook of Musical Development (s. 3-14). Oxford: Oxford University Press.

Provasi, J., Anderson, D.I., Barbu-Roth, M. (2014). Rhythm perception, production, and synchronization during the perinatal period. Frontiers in Psychology, 5(1048), 1-16.

Raphael-Leff, J. (1993). Pregnancy: the inside story. London: Sheldon Press.

Saliba, S., Gratier, M., Filippa, M., Devouche, E., Esseily, R. (2020). Fathers' and mothers' infant directed speech influences preterm infant behavioral state in the NICU. Journal of Nonverbal Behavior, 44(4), 437-451.

Spence, M.J., DeCasper, A.J. (1987). Prenatal experience with low-frequency maternal-voice sounds influence neonatal perception of maternal voice samples. Infant Behavior and Development, 10, 133-142.

Stern, D. (1998). The Birth of a Mother. New York: Basic Books.

Van de Carr, F.R. (1998). Prenatal university: commitment to fetal-family bonding and the strengthening of the family unit as an educational institution. Journal of Prenatal and Perinatal Psychology and Health, 12(3), 119-134.

Vasta, R., Haith, M.M., Miller, S.A. (2004). Psychologia dziecka. Warszawa: Wydawnictwa Szkolne i Pedagogiczne.

Voegtline, K.M., Costigan, K.A., Pater, H.A., DiPietro, J.A. (2013). Near-term fetal response to maternal spoken voice. Infant Behavior and Development, 36, 526-533.

Walker, M., Conner, G. (1993). Fetal sex preference of second-trimester gravidas. Journal of Nurse-Midwifery, 38(2), 110-113.

Williamson, S., McGrath, J.M. (2020). Neonatal nurses’ self-reported practices, knowledge, and attitudes toward use of maternal voice for preterm infants. Advances in Neonatal Care, 20(5), 415-422. DOI: 10.1097/ANC.0000000000000715.

Zeanah, C.H., Keener, M.A., Stewart, L., Anders, T.F. (1985). Prenatal perception of infant personality: A preliminary investigation. Journal of the American Academy of Child Psychiatry, 24, 204-210. 